\title{
A review of the use of somatostatin analogs in oncology
}

This article was published in the following Dove Press journal:

OncoTargets and Therapy

25 April 2013

Number of times this article has been viewed

\author{
Ozge Keskin \\ Suayib Yalcin \\ Department of Medical Oncology, \\ Hacettepe University Institute of \\ Cancer, Ankara, Turkey
}

Correspondence: Suayib Yalcin Department of Medical Oncology, Hacettepe University Institute of Cancer, Sihhiye,

Ankara 06100, Turkey

Tel +903123052937

Fax +90312305 2935

Email syalcin@hacettepe.edu.tr

\begin{abstract}
Somatostatin is a neuropeptide produced by paracrine cells that are located throughout the gastrointestinal tract, lung, and pancreas, and is also found in various locations of the nervous system. It exerts neural control over many physiological functions including inhibition of gastrointestinal endocrine secretion through its receptors. Potent and biologically stable analogs of somatostatin have been developed. These somatostatin analogs show different efficacy on different receptors, and receptors are varyingly concentrated in specific tissues. Antitumor and antisecretory effects of somatostatin analogs in cancer have been shown in several in vivo and in vitro studies. However, these activities have not always yielded into clinically relevant patient outcome benefit. Somatostatin analogs are of clinical benefit in treating symptoms of ectopic hormone secretion (adrenocorticotropic hormone, growth hormone-releasing hormone) in lung cancer, without inducing a significant tumor response. They have also been shown to induce a statistically significant decrease in bone pain and increase in Karnofsky performance status in patients with metastatic prostate cancer. Somatostatin analogs alone or in combination with other agents have only limited antitumoral effect in breast cancer. In gastrointestinal cancers, studies have not shown an objective tumor response to somatostatin analogs except in endocrine tumors of the liver with symptomatic and biochemical improvement. In neuroendocrine tumors of the gastrointestinal system and pancreas, very high symptomatic and biochemical response rates have been achieved with somatostatin analogs. Antiproliferative activity has been clearly shown in metastatic midgut neuroendocrine tumors.
\end{abstract}

Keywords: somatostatin analogs, oncology, radiolabeled, cancer

\section{Introduction}

Somatostatin is a neuropeptide produced by paracrine cells that are located throughout the gastrointestinal tract, and is also found in various locations in the nervous system. It has important roles in controlling autocrine, paracrine, and endocrine functions. ${ }^{1,2}$ Besides the control of growth hormone secretion by the hypothalamic phase, somatostatin also controls many pituitary, pancreatic, and gastrointestinal hormone secretion (eg, thyroid stimulating hormone, insulin, glucagon, gastric acid). ${ }^{1-3}$ It inhibits intestinal motility and absorption, vascular contractility, and cell proliferation. In addition, somatostatin is a neurotransmitter regulating locomotor activity and cognitive functions. ${ }^{3}$

Somatostatin molecule has two biologically active forms: somatostatin-14 and somatostatin-28. ${ }^{1}$ Prosomatostatin, which is a prohormone, develops from a precursor called preprosomatostatin consisting of 116 amino acids. Biologically active somatostatin is generated by proteases from prosomatostatin. Somatostatin has receptors on normal host cells and exhibits activity through these receptors. To date, five subtypes 
have been recognized: somatostatin receptor 1-5 (SSTR1-5). Various somatostatin analogs show different efficacy on different receptors (Table 1), and receptors are varyingly concentrated in specific tissues (Table 2).

\section{Antitumoral activity of somatostatin}

Antitumor and antisecretory effects of somatostatin in cancer have been shown in several in vivo and in vitro studies. Antitumoral activity occurs through the G-protein coupled receptors on target cells ${ }^{3}$ and SSTRs on tumor cells. ${ }^{4}$ SSTRs are associated with guanine nucleotide binding proteins (G proteins) and through them somatostatin inhibits adenyl cyclase and sodium/hydrogen exchange activity, ${ }^{3}$ and increases intracellular calcium mobilization by the phospholipase $\mathrm{C}$ stimulation. Major intracellular pathways of somatostatin effects include inhibition of adenyl cyclase, activation of potassium/calcium channels, activation of protein phosphatases, and activation of intracellular tyrosine phosphatase. In addition, somatostatin has an indirect antiproliferative effect on tumors by the inhibition of growth factors and tumor angiogenesis. ${ }^{5}$ Antiproliferative activity of somatostatin analogs have been demonstrated in breast, kidney, lung, prostate, cervix, and colon cancer studies in vitro. ${ }^{1,3}$ This activity may be directly related to the inhibition of cell growth signaling pathways, or by indirect mechanisms through the SSTRs on normal host cells. The direct and indirect mechanisms of antitumoral activity of somatostatin analogs are summarized in Tables 3 and 4.

\section{Pharmacology of long-acting somatostatin analogs}

Native somatostatin has a very short serum half-life because of the enzymatic degradation; however, more potent and

Table I Somatostatin analogs' affinity to receptor subtypes ${ }^{6,7}$

\begin{tabular}{ll}
\hline Somatostatin analogs & Receptor subtypes \\
\hline Octreotide & SSTR2, SSTR5 \\
RC-I60 (vapreotide) & SSTR2, SSTR5 \\
Lanreotide (BIM230I4) & SSTR2, SSTR5 \\
SOM 230 & SSTRI-3, SSTR5 \\
Woc-4D & SSTR2 \\
JDL & SSTR2 \\
CH-275 & SSTRI \\
TT2-32 & SSTRI \\
BIM23052 & SSTR5 \\
BIM23056 & SSTR3 \\
BIM23066 & SSTR2 \\
L-362855 & SSTR5 \\
KEI08 & All SSTRs \\
\hline
\end{tabular}

Abbreviation: SSTR, somatostatin receptor.
Table 2 Localization of receptor subtypes ${ }^{7,8}$

\begin{tabular}{ll}
\hline SSTR subtype & Localization \\
\hline SSTRI & Brain cortex, amygdala, gastrointestinal tract \\
SSTR2 & Brain cortex, pituitary, adrenals \\
SSTR3 & Brain, cerebellum, pituitary \\
SSTR4 & Brain, heart, pancreatic islets \\
SSTR5 & Brain, hypothalamus, pituitary \\
\hline
\end{tabular}

Abbreviation: SSTR, somatostatin receptor.

long-acting analogs of somatostatin have been developed and they are biologically stable. During the development of stable analogs, L-amino acid form was replaced by its D-isomer at position-8, D-amino acid was introduced at N-terminus and an amino alcohol was added at the C-terminus. As a result of these changes, the native form became more stable against the enzymatic degradation. The disulfide bridge in the long-acting forms also has a protective effect against the endopeptidases. Native somatostatin and its derived peptides are shown in Figures 1 and $2 .^{8}$

Octreotide long-acting repeatable (LAR) is a long-acting somatostatin analog, formed by incorporating octreotide into microspheres of a biodegradable polymer and used as a monthly injection. After a single intramuscular injection, a serum peak develops initially followed by a decrease in drug concentration between the second and seventh day. However, with a slow increase again, a plateau phase occurs between days $14-42.8$ Injections with 4-week intervals provide a constant and stable serum drug concentration. Toxicity of microspheres is low and well tolerated due to biodegradation at 10-12 weeks. There are three dosage forms used in clinical routine practice: $10 \mathrm{mg}$, $20 \mathrm{mg}$, and $30 \mathrm{mg}$. The most frequent side effects are related to the gastrointestinal tract, glucose metabolism, and cholelithiasis. Adverse effects associated with the injection site are usually mild and short in duration. Adverse effects of long-acting somatostatin analogs are summarized in Table 5.

The other slow-release form of somatostatin analog is lanreotide. In healthy volunteers and acromegalic patients,

Table 3 Direct mechanisms of antitumoral activity of somatostatin analogs 6,10

I. Phosphotyrosine phosphatase activation

2. Tyrosine kinase inhibition

3. GI arrest in cell cycle by the downregulation of phosphorylation

4. Cell cycle arrest by Ras/mitogen-activated protein kinase pathway activation

5. Apoptosis of cancer cells by intracellular acidification, endonuclease activation, and protein-53-Bax induction

6. Inhibition of mitogenic hormones, growth factors, and cytokines through the inhibition of cyclic adenosine monophosphate and calcium production 
Table 4 Indirect mechanisms of antitumoral activity of somatostatin analogs $s^{6,10}$

I. Inhibition of growth factors exocrine and endocrine secretion (epidermal growth factor, basic fibroblast growth factor, insulin-like growth factor- I-2, insulin-like growth factor binding protein)

2. Immune modulating effects: lymphocyte proliferation, immunoglobulin synthesis, inhibition of cluster of differentiation-4+ T-cells derived interferon- $\gamma$ synthesis

3. Inhibition of tumor angiogenesis (this effect is mediated predominantly through SSTR2, and to a lesser extent SSTRI and SSTR4) $)^{5,8,11}$

4. Inhibition of fibroblast and monocyte cell migration and adhesion

Abbreviation: SSTR, somatostatin receptor.

the maximum serum concentration is obtained in the second hour after injection. Serum concentration continues to decrease slowly until the eleventh day, and is maintained for up to 2 weeks. Serum half-life is $4.52 \pm 0.50$ days ${ }^{8,12}$ The form containing $30 \mathrm{mg}$ of drug is used in 2-week intervals. The side effect profile is similar to octreotide. Octreotide LAR with $20-90 \mathrm{mg} / \mathrm{month}$ and lanreotide slow release with $60-120 \mathrm{mg} / \mathrm{month}$ dosage studies, including acromegalic patients and neuroendocrine tumors, provided palliation of symptoms, and significant toxicity related to increasing dose was not observed..$^{13}$ In studies comparing the efficacy of these two forms in patients with acromegaly, controversial results have been obtained. ${ }^{14-16}$ The data in neuroendocrine tumors will be discussed in later sections.

\section{Somatostatin analogs in breast cancer}

Expression of SSTRs has been shown in approximately $60 \%$ of breast cancer specimens. However, the distribution of these receptors in the tumor tissue is not homogenous. Increased expression of SSTRs are more common in patients with positive estrogen and progesterone receptor with low epidermal growth factor receptor expression. ${ }^{10,17}$ The antiproliferative

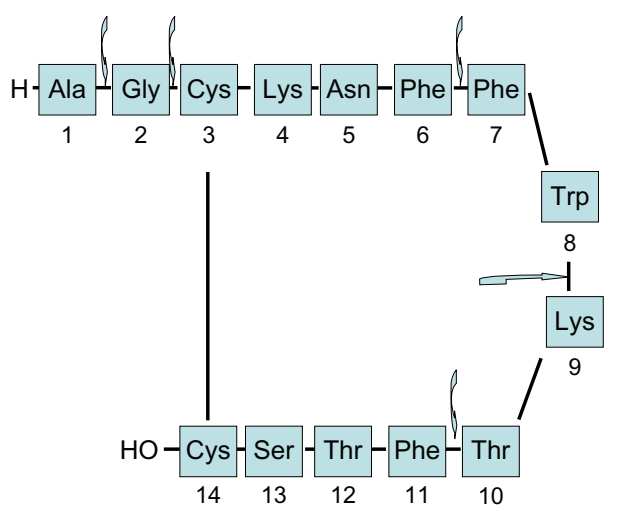

Figure I Structure and enzymatic degradation regions of native somatostatin.

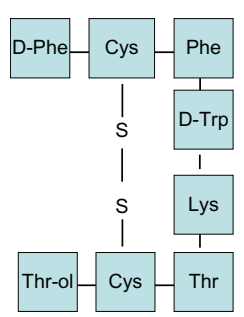

Octreotide sandostatin

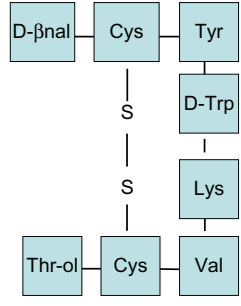

Lanreotide somatuline ${ }^{\oplus}$

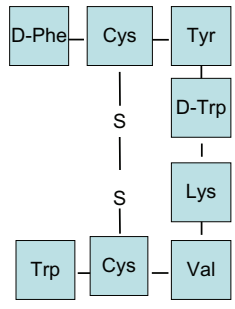

Vapreotide octastatin ${ }^{\oplus}$
Figure 2 Structure of octreotide and its derived peptides.

effect of somatostatin in breast cancer has been suggested to be mediated through SSTR2 and SSTR5.${ }^{17}$ In a study by Vennin et al, only three of 16 postmenopausal patients treated with octreotide had stable disease without any objective response. ${ }^{18}$ In another study, ten postmenopausal women were treated with a combination of bromocriptine and octreotide and stable disease was observed in only one patient. ${ }^{19}$ In a study by Stolfi et al, partial response was seen in three of ten patients with octreotide. ${ }^{20}$ Anderson et al used a combination of bromocriptine and octreotide in six patients and stable disease was obtained in four patients. ${ }^{21}$ Canobbio et al treated 36 previously untreated postmenopausal patients with locally advanced or metastatic breast cancer with lanreotide and tamoxifen. Four patients had complete response and twelve patients had partial response. ${ }^{22}$ Di Leo et al reported no response to lanreotide in ten patients with advanced breast cancer. ${ }^{23}$ O'Byrne et al treated 14 advanced breast cancer patients with vapreotide. No objective tumor response was observed..$^{19}$ In another study, 135 postmenopausal women with metastatic breast cancer were randomized to tamoxifen alone or in combination with octreotide. Objective response rates were $49 \%$ and $43 \%$ in the tamoxifen and combination arm, respectively. ${ }^{24}$ Bajetta et al randomized previously untreated metastatic breast cancer patients to tamoxifen combined with either placebo or octreotide. No difference was

Table 5 Side effects of somatostatin analogs

\begin{tabular}{ll}
\hline Most common & Nausea \\
& Abdominal pain \\
& Headache \\
& Dizziness \\
& Fatigue \\
& Back pain \\
& Gallbladder abnormalities \\
Biliary effects & New gallstones \\
Glucose metabolism & Hyperglycemia \\
Cardiac events & Hypoglycemia \\
& Sinus bradycardia \\
& Conduction abnormalities \\
& Arrhythmias \\
\hline
\end{tabular}


observed between groups in tumor response and median time to progression. ${ }^{25}$ Combination of octreotide with tamoxifen and an antiprolactin drug was studied by Bontenbal et al. They randomized 22 metastatic breast cancer patients to tamoxifen or combination therapy. Objective response rates were $36 \%$ and $55 \%$ in the monotherapy and combination arm, respectively. ${ }^{26}$ With these results it is clear that somatostatin analogs alone or with other agents (tamoxifen, antiprolactin agents) have a very limited effect in the treatment of breast cancer. Table 6 provides a summary of these studies.

\section{Somatostatin analogs in lung cancer}

Although high SSTR expression has been reported in both small-cell lung cancer (SCLC) and non-SCLC, the results obtained with somatostatin analogs in various studies in patients with SCLC and non-SCLC show huge variation. Elevated serum or plasma somatostatin levels can be detected depending on the primary disease, and also may be due to ectopic release from tumor tissue. ${ }^{4}$ Studies have shown high expression of SSTR, mainly SSTR2 in SCLC. ${ }^{27}$ Expression of these receptors were not detected in first trials of non-SCLC, and somatostatin analogs were thought to bind to receptors in the tumor microenvironment. Increased SSTR expression has also been shown in lung well-differentiated neuroendocrine tumors (bronchial carcinoids) in comparison to SCLC and non-SCLC. ${ }^{4,28}$ There is a limited number of clinical studies with a limited number of patients with SCLC (Table 7). In a study including 20 patients (six newly diagnosed and 14 relapsed disease), insulin-like growth factor-1 level decreased significantly with octreotide (250 $\mu \mathrm{g} /$ day), but tumor burden did not change. ${ }^{27}$ However, somatostatin analogs have been successfully used in treating paraneoplastic conditions in patients with SCLC, in addition to controlling the clinical symptoms of ectopic hormone secretion (adrenocorticotropic hormone, growth hormone-releasing hormone) in bronchial carcinoids, without providing a significant objective tumor response. ${ }^{29-31}$

In another study, patients with limited stage and advanced stage SCLC were divided into three groups: chemotherapy alone (paclitaxel $190 \mathrm{mg} / \mathrm{m}^{2}$ plus carboplatin area under the curve $=5.5$ ) versus chemotherapy plus $30 \mathrm{mg}$ lanreotide versus chemotherapy plus $60 \mathrm{mg}$ lanreotide. Patients with limited disease in the chemotherapy plus $30 \mathrm{mg}$ lanreotide arm had a significantly better median survival and median time to progression compared to the other groups. ${ }^{2}$ In advanced stage patients, no statistically significant differences were observed.

Table 6 Summary of the studies with somatostatin and its analogs alone or in combination with other agents in breast cancer

\begin{tabular}{|c|c|c|c|c|c|}
\hline Study & Treatment and dosage & Patient & ORR (\%) & OR & Limitations \\
\hline Vennin et $a^{18}$ & Octreotide $200 \mu \mathrm{g} /$ day & 16 & - & $3 \mathrm{SD}$ & Lack of patient number \\
\hline Manni et $\mathrm{al}^{79}$ & $\begin{array}{l}\text { Octreotide } 200-400 \mu \mathrm{g} / \text { day } \\
\text { and bromocriptine } 5 \mathrm{mg} / \text { day }\end{array}$ & 10 & - & I SD & Lack of patient number \\
\hline Stolfi et a $\left.\right|^{20}$ & $\begin{array}{l}\text { Octreotide } 750 \mu \mathrm{g} \text { for } 10 \text { days, } \\
\text { then } 500 \mu \mathrm{g} \text { for } 5 \text { days }\end{array}$ & 10 & - & $3 P R$ & Lack of patient number \\
\hline Anderson et $\mathrm{a}^{21}$ & $\begin{array}{l}\text { Octreotide } 200-400 \mu \mathrm{g} / \text { day } \\
\text { and bromocriptine } 2.5-5 \mathrm{mg} / \text { day }\end{array}$ & 6 & - & $4 \mathrm{SD}$ & Lack of patient number \\
\hline Canobbio et $\mathrm{a}^{22}$ & $\begin{array}{l}\text { Lanreotide } 20-30 \mathrm{mg} / 2 \text { weeks } \\
\text { and tamoxifen } 30 \mathrm{mg} / \text { day }\end{array}$ & 36 & 52 & $\begin{array}{l}4 \mathrm{CR} \\
12 \mathrm{PR}\end{array}$ & $\begin{array}{l}\text { Lack of patient number; } \\
\text { previously untreated } \\
\text { patients }\end{array}$ \\
\hline Di Leo et $\mathrm{al}^{23}$ & Lanreotide $30 \mathrm{mg} / 2$ weeks & 10 & - & None & $\begin{array}{l}\text { Lack of patient number; } \\
\text { advanced disease }\end{array}$ \\
\hline O'Bryne et al' ${ }^{19}$ & $\begin{array}{l}\text { Vapreotide } 3 \mathrm{mg} / \text { day initially, } \\
\text { then } 4.5 \mathrm{mg} / \text { day and } 6 \mathrm{mg} / \mathrm{day}\end{array}$ & 14 & - & None & $\begin{array}{l}\text { Lack of patient number; } \\
\text { advanced disease }\end{array}$ \\
\hline Ingle et $\mathrm{a}^{24}$ & $\begin{array}{l}\text { Tamoxifen } 20 \mathrm{mg} / \text { day versus } \\
\text { tamoxifen } 20 \mathrm{mg} / \text { day }+ \\
\text { octreotide } 300 \mu \mathrm{g} / \text { day }\end{array}$ & 135 & 49 versus 43 & $\begin{array}{l}\text { II CR + PR versus I } 3 \mathrm{CR}+ \\
\text { PR according to individual } \\
\text { criteria }\end{array}$ & $\begin{array}{l}\text { TTP: } 14.2 \text { months versus } \\
\text { I0.3 months; } 3 \text {-year } \\
\text { survival rate: } 58 \% \text { versus } \\
56 \% \text {; metastatic disease }\end{array}$ \\
\hline Bajetta et $\mathrm{al}^{25}$ & $\begin{array}{l}\text { Tamoxifen + placebo versus } \\
\text { tamoxifen + octreotide }\end{array}$ & 203 & 21 versus 20 & - & $\begin{array}{l}\text { Previously untreated } \\
\text { patients; metastatic } \\
\text { disease }\end{array}$ \\
\hline Bontenbal et $\mathrm{a}^{26}$ & $\begin{array}{l}\text { Tamoxifen } 40 \mathrm{mg} / \text { day versus } \\
\text { tamoxifen } 40 \mathrm{mg} / \text { day + } \\
\text { octreotide } 0.6 \mathrm{mg} / \text { day + } \\
\mathrm{CV} 205-50275 \mu \mathrm{d} / \text { day }\end{array}$ & 22 & 36 versus 55 & $\begin{array}{l}4 C R+P R \text { versus } 5 C R+ \\
P R \text { according to UICC }\end{array}$ & $\begin{array}{l}\text { TTP: } 33 \text { weeks versus } \\
84 \text { weeks; time interval } \\
\text { was short for conclusion; } \\
\text { lack of patient number }\end{array}$ \\
\hline
\end{tabular}

Abbreviations: $C R$, complete response; OR, objective response; ORR, overall response rate; PR, partial response; SD, stable disease; TTP, time to progression; UICC, Union for International Cancer Control. 
Table 7 Summary of the results obtained with chemotherapy \pm somatostatin analog in small-cell lung cancer

\begin{tabular}{lllllll}
\hline & $\begin{array}{l}\text { Stage, } \% \\
\text { (LS/AS) }\end{array}$ & CR (\%) & PR (\%) & OR (\%) & Median survival, days & Median TTP, days \\
\hline Group A & $36 / 64$ & $7(15)$ & $17(36)$ & $24(52)$ & 300 & 224 \\
Group B & $44 / 56$ & $13(30)$ & $18(42)$ & $30(72)$ & $476(P=0.029)$ & $350(P=0.034)$ \\
Group C & $45 / 55$ & $4(10)$ & $15(37)$ & $17(47)$ & 347 & 294 \\
\hline
\end{tabular}

Notes: Response was assessed according to the Veterans Administration Lung Group; group A, chemotherapy alone (paclitaxel $190 \mathrm{mg} / \mathrm{m}^{2}+$ carboplatin area under the curve $=5.5$ ); group B, chemotherapy plus $30 \mathrm{mg}$ lanreotide; group $C$, chemotherapy plus $60 \mathrm{mg}$ lanreotide.

Abbreviations: AS, advanced stage; CR, complete response; LS, limited stage; OR, objective response; PR, partial response; TTP, time to progression.

A patient with advanced stage SCLC with poor general condition benefitted from octreotide treatment. ${ }^{32}$ In a Phase I study, two patients with SCLC responded to lanreotide, with an objective tumor response observed in one patient. ${ }^{28}$ Generally, somatostatin analogs have not been shown to induce an obvious decrease in tumor burden in lung cancer, but may enhance chemotherapy activity due to an antiproliferative effect, especially in patients with limited stage SCLC.

\section{Somatostatin analogs in prostate cancer}

Since SSTR expression has been shown in prostate cancer in both in vivo and in vitro studies, the combination of chemotherapy with somatostatin analogs has been investigated in some clinical studies (Table 8). In a study including stage D2 prostate cancer patients who relapsed after castration and flutamide, somatostatin analogs alone or in combination with bromocriptine were tested. ${ }^{7}$ In another study including 16 hormone-refractory metastatic prostate cancer patients, a partial response was observed in two patients treated with lanreotide. ${ }^{33}$ Only progressive disease was observed in another study testing the efficacy of octreotide. However, regression was observed with subsequent therapies used for the progressive disease, and it is suggested that octreotide had sensitized the tumor cells to subsequent chemotherapies. ${ }^{34}$ In a study including 18 patients with stage D2 prostate cancer, 14 of them were treated with a combination of total androgen blockade and octreotide. The total response rate was $33 \%$. Mean disease free survival was 12 months and 17 months in the androgen blockade arm and combination arm, respectively. Mean overall survival was similar between the two groups (18.5 months versus 18 months). ${ }^{36}$ Koutsilieris et al reported improvement in performance status and a decrease in prostate-specific antigen (PSA) levels in four castrationresistant prostate cancer patients with combination therapy of triptorelin, lanreotide, and dexamethasone treatment for 2 months. ${ }^{36}$ Additionally, the number of patients increased, there was an improvement in quality of life, and a decrease in PSA levels. ${ }^{36}$ Within 6 months of combination therapy (triptorelin, lanreotide, and dexamethasone), PSA decline in ten of eleven patients had been established. A concurrent decrease in pain related to bone metastases (with a median duration of 13 months) and improvement in performance status (Eastern Cooperative Oncology Group performance status less than two with a median of 11 months) were detected. Median disease free survival was 7 months and median overall survival was 18 months. ${ }^{36}$ Dimopoulos et al treated 40 patients with hormone-resistant prostate cancer with either estramustine plus etoposide or lanreotide plus dexamethasone in addition to surgical or medical androgen ablation. Data of 38 patients (20 in the estramustine plus etoposide group and 18 in the lanreotide plus dexamethasone group) were analyzed. PSA responses and partial clinical responses (improvement in performance status and decrease in pain) were observed. But the difference was not statistically significant between the groups. Overall survival was also similar (18.8 months versus 18 months in the estramustine plus etoposide and lanreotide plus dexamethasone groups, respectively) ${ }^{37} \mathrm{In}$ another study including 38 patients with stage D3 androgen ablation-resistant metastatic prostate cancer, bone metastases were observed at the time of diagnosis. These patients were randomized into two arms. In the first arm, zoledronic acid was used in combination with octreotide and dexamethasone; in the second arm, only zoledronic acid was used. Two groups were monitored for symptom palliation. The study was terminated early due to the differences in disease free survival and overall survival rates. Disease free survival was 7 months and 1 month and overall survival was 12 months and 9 months in the first and second arm, respectively. ${ }^{38}$ In a study with lanreotide and ethinyl estradiol combination, ten patients with stage D3 metastatic hormone-resistant disease were included. In nine of these patients, PSA levels decreased more than $50 \%$ and palliation of metastatic bone pain was reported in all patients. ${ }^{39}$ In a study evaluating the effect of somatostatin analog RC-160 (vapreotide) at the time of relapse, 13 patients with stage D3 androgen-independent metastatic prostate cancer were included. Eight patients had been treated with a depot formulation of luteinizing hormone-releasing hormone agonist. Five patients were initially treated with 
Table 8 Selected studies with somatostatin and its analogs in combination with other agents in prostate cancer

\begin{tabular}{|c|c|c|c|c|}
\hline Study & Treatment and dosage & Patients, $\mathbf{n}$ & Survival, months & Limitations \\
\hline Vainas et $\mathrm{a}^{35}$ & $\begin{array}{l}C A B \text { (castration or triptorelin }+ \\
\text { flutamide) versus } C A B+\text { octreotide } \\
\text { ( } 0.4 \mathrm{mg} / \text { day for } \geq 12 \text { months) }\end{array}$ & $\begin{array}{l}4 \text { versus } 14 \\
\text { (total } 18 \text { ) }\end{array}$ & DFS: 12 versus 17 & $\begin{array}{l}\text { Lack of patient } \\
\text { number }\end{array}$ \\
\hline Koutsilieris et $\mathrm{a}^{36}$ & $\begin{array}{l}\text { Triptorelin }(3.75 \mathrm{mg} / 28 \text { days })+ \\
\text { oral dexamethasone }(4 \mathrm{mg} \text { tapered } \\
\text { to } 1 \mathrm{mg})+ \text { lanreotide } \\
(30 \mathrm{mg} / \mathrm{l} 4 \text { days })\end{array}$ & 11 & $\begin{array}{l}\text { PFS (median): } 7 \text { (according to PSA } \\
\text { Working Group criteria); } \\
\text { OS (median): I8; } \\
\text { All achieved ECOG/WHO scores }<2 \\
\text { and improvement in bone pain; } \\
\text { PSA decline }>50 \% \text { of baseline levels } \\
\text { in eight responders }\end{array}$ & $\begin{array}{l}\text { Lack of patient } \\
\text { number; not a } \\
\text { randomized study }\end{array}$ \\
\hline Dimopoulos et al ${ }^{37}$ & $\begin{array}{l}\text { Estramustine } 420 \mathrm{mg} / \text { day }+ \\
\text { etoposide } 100 \mathrm{mg} / \text { day versus } \\
\text { lanreotide } 30 \mathrm{mg} / \mathrm{l} 4 \text { day }+ \\
\text { dexamethasone }(4 \mathrm{mg} \text { tapered } \\
\text { to } 1 \mathrm{mg} \text { ) }\end{array}$ & $\begin{array}{l}40 \text { ( } 38 \text { were } \\
\text { analyzed) }\end{array}$ & $\begin{array}{l}\text { OS: } 18.8 \text { versus } 18 \\
\text { TTP: } 6 \text { versus } 4\end{array}$ & \\
\hline Mitsiades et al ${ }^{38}$ & $\begin{array}{l}\text { Zoledronate }(4 \mathrm{mg} / 4 \text { weeks }) \\
\text { versus zoledronate + octreotide } \\
(20 \mathrm{mg} / 28 \text { days })+\text { oral } \\
\text { dexamethasone }(4 \mathrm{mg} \text { tapered } \\
\text { to } 1 \mathrm{mg})\end{array}$ & $\begin{array}{l}38 \\
(18 \text { versus } 20)\end{array}$ & $\begin{array}{l}\text { PFS: I versus } 7(P<0.000 \text { I); } \\
\text { OS: } 9 \text { versus I }(P<0.05) \text {; } \\
\text { Prostate cancer specific OS: } \\
9 \text { versus I4 }(P<0.05)\end{array}$ & $\begin{array}{l}\text { Zoledronate } \\
\text { monotherapy arm } \\
\text { did not receive } \\
\text { dexamethasone }\end{array}$ \\
\hline Gonzalez-Barcena et al ${ }^{40}$ & $\begin{array}{l}\text { Vapreotide I } \mathrm{mg}+\text { LHRH analog } \\
(3.75 \mathrm{mg} / \mathrm{month}) / \text { ketoconazole } \\
(600-800 \mathrm{mg} / \text { day }) \text { in the } \\
\text { orchiectomy group }\end{array}$ & 13 & $\begin{array}{l}\text { Median survival: } 19 \text { months in } \\
R \text { versus } 5 \text { months in NR }(P<0.05) \text {; } \\
C R \text { in two patients, PR in four patients, } \\
\text { and } S R \text { in two patients (according to } \\
\text { ECOG recommendations for the } \\
\text { PSA evaluation) }\end{array}$ & $\begin{array}{l}\text { Lack of patient } \\
\text { number; no } \\
\text { difference in } \\
\text { response to } \\
\text { vapreotide was } \\
\text { observed between } \\
\text { the patients }\end{array}$ \\
\hline
\end{tabular}

Abbreviations: CAB, complete androgen blockade; CR, complete response; DFS, disease free survival; ECOG, Eastern Cooperative Oncology Group; LHRH, luteinizing hormone-releasing hormone; NR, nonresponder; OS, overall survival; PFS, progression-free survival; PR, partial response; PSA, protein-specific antigen; R, responder; RR, response rate; SR, stable response; TTP, time to progression; WHO, World Health Organization.

surgical orchiectomy, then with ketoconazole at the time of first relapse. All patients received vapreotide in addition to luteinizing hormone-releasing hormone agonist or ketoconazole at the time of relapse. Six patients had a statistically significant decrease in PSA level and two additional patients achieved a decrease in serum prostatic acid phosphatase levels. Patients who responded to the therapy showed a statistically significant decrease in bone pain and increase in Karnofsky performance status. ${ }^{40}$

As a monotherapy in prostate cancer, somatostatin analogs seem to have limited effect; however, favorable results have been reported when administered in combination with prostate cancer-specific anticancer agents. To prove the efficacy of somatostatin analogs, studies with a greater number of patients are needed to show the role of somatostatin analogcontaining combination regimens in prostate cancer.

\section{Somatostatin analogs in gastrointestinal cancer}

Hormonal therapies have been tested in chemotherapy-resistant gastrointestinal cancers, since some of these tumors might be hormone dependent. Hormone and growth factor secretion by the gastrointestinal tract is inhibited by somatostatin. ${ }^{41}$ Therefore, somatostatin analogs have been tested to inhibit the secretory functions of the tumoral cells. A limited number of clinical studies have been conducted, ${ }^{42}$ and results have not been favorable so far. In general, studies did not show an objective tumor response and survival advantage..$^{41,43}$ The lack of knowledge on the optimal dose and timing of somatostatin analog administration may be the reason for unfavorable results.

In the study of Klijn et al, a heterogeneous group of 34 metastatic gastrointestinal tumor patients (14 patients with pancreas cancer, 16 patients with colorectal cancer, and four patients with gastric cancer; 14 patients having received prior chemotherapy) were included. These patients were treated with somatostatin analog and stable disease was observed in three pancreatic, four colorectal, and one gastric cancer patient as a best response. Progressive disease was seen in the remaining 21 patients. Pain palliation was achieved in the majority of patients. ${ }^{42}$

Studies thus far have failed to show any objective tumor response for pancreatic cancer. Friess et al treated 22 cases 
of advanced pancreatic cancer. Partial or complete remission was not observed in any patient. Three patients had no radiological change in tumor burden for 8 weeks. The median survival for all patients was 20 weeks. ${ }^{45}$ However, Rosenberg et al demonstrated a survival advantage with the combination of octreotide and tamoxifen for pancreatic cancer. In this study, twelve patients who received this combination therapy were compared with the previously untreated 68 patients. Median survival and 1-year survival in the combination arm versus untreated arm were 12 months versus 3 months and $59 \%$ versus $16 \%$, respectively. ${ }^{41}$ Antitumoral efficacy of octreotide and goserelin combination was examined in 14 patients with advanced stage pancreatic cancer. One patient had partial response and three patients had progressive disease. Nine of the patients had stable disease during 27 months. Time to progression was $3 \pm 1.8$ months. Overall survival for all the patients was $6 \pm 1.5$ months. ${ }^{43}$ In another study, locally unresectable, recurrent, or metastatic pancreatic adenocarcinoma cases were divided into three groups: octreotide monotherapy versus 5-fluorouracil-containing chemotherapy versus 5-fluorouracil plus leucovorin combination therapy. Patients who progressed after octreotide therapy were randomized to the other two chemotherapy groups. The time to progression was 42 days in the octreotide arm and 105 days in the combined chemotherapy arm. There was no statistically significant difference in overall survival, which was explained by the randomization of patients to the chemotherapy arm after the first progression. ${ }^{45}$ In a Phase II study, high-dose octreotide was used in inoperable pancreatic carcinoma. Stable disease was observed in nine of 47 patients. Partial or complete remission was not observed in any patient. The median overall survival was 21.4 weeks and median progression-free survival was 9 weeks. ${ }^{46}$

In a study with advanced gastrointestinal cancer (pancreas, stomach, and colorectal cancers), patients who progressed after first-line chemotherapy were randomized into two groups. The first group was treated with somatostatin, and supportive care was given to the second group. Objective tumor response was not observed in any patient. Stable disease ratios were $45 \%$ and $15 \%$ in the first and second group, respectively, according to the criteria of Miller et al $(P<0.05)$. Median survival was 20 weeks and 11 weeks in the first and second group, respectively. ${ }^{47}$ Long-acting somatostatin analog (SMS 201.995) effect on tumor markers and Ki-67 was examined in patients with primary rectal adenocarcinoma. There were 13 patients in the treatment arm and six patients in the untreated control arm. Ki-67 staining of the primary tumor in four of twelve patients in the treatment arm was decreased. Serum carcinoembryonic antigen level was increased in four patients in the treatment arm after the surgery. In two of these patients, carcinoembryonic antigen level was decreased by the somatostatin analog treatment. These results led Iftikhar et al to suggest that somatostatin analog therapy can alter the tumor kinetics. ${ }^{48}$

Table 9 provides a summary of somatostatin analogs in combination with other agents in gastrointestinal cancer.

\section{Somatostatin analogs in hepatobiliary cancers}

About $40 \%$ of hepatocellular carcinomas express SSTRs. Antitumoral effect of somatostatin was observed in hepatic tumors of animal models and in sporadic case reports and some small clinical studies. A previous trial including 58 patients treated with short-acting octreotide $250 \mu \mathrm{g}$ subcutaneously, twice daily, reported by Kouroumalis suggested a survival advantage for short-acting octreotide compared with best supportive care (median survival 13 months and 4 months, respectively; $P=0.002) .{ }^{49}$ However, the randomized, controlled, double-blind HECTOR (Study to Evaluate the Efficacy of Octreotide in Patients With Inoperable Hepatocellular Carcinoma) trial showed no survival benefit for hepatocellular carcinoma patients treated with long-acting octreotide compared with placebo. ${ }^{50}$ In a systematic review, octreotide was shown to improve the survival -6 months and 12 months in some of the groups - in advanced hepatocellular carcinoma. Some studies including the octreotide group versus no treatment group showed 6 months versus 12 months of survival superiority in the octreotide group. Studies in China and studies including more than 50 patients also reported a similar survival advantage with octreotide. The variation in the treatment outcomes and survival benefit of octreotide treatment in hepatocellular carcinoma may be explained by the differences in patient characteristics and SSTR variations. ${ }^{51}$

Limited preclinical studies showed the presence of SSTR in cholangiocarcinoma. ${ }^{52}$ Due to the presence of SSTR, somatostatin analogs inhibit the cell growth. However, there are no clinical studies on somatostatin analog treatment in cholangiocarcinoma.

\section{Somatostatin analogs in pediatric tumors}

Few data are available in neuroendocrine tumors of childhood..$^{53}$ In a 25-year experience of Texas Children's Hospital, carcinoid tumor of the lung was found to be the minority cause of lung masses. Surgical intervention was preferred as the primary treatment. ${ }^{54}$ 
Table 9 Somatostatin and its analogs in combination with other agents in gastrointestinal cancer

\begin{tabular}{|c|c|c|c|c|}
\hline Study & Treatment and dosage & Patient & Results & Limitations \\
\hline Klijn et $\mathrm{al}^{42}$ & Octreotide $300-600 \mu g /$ day & 34 & $\begin{array}{l}\text { SD: } 27 \% \text { (for } 3-9 \text { months); } \\
\text { PD: } 73 \% \text {; } \\
\text { Median survival: } 2 \text { months for pancreatic } \\
\text { cancer, } 8 \text { months for colorectal cancer }\end{array}$ & No survival advantage \\
\hline Friess et $\mathrm{a}^{\mathrm{l}^{44}}$ & Octreotide $300-600 \mu g /$ day & 22 & $\begin{array}{l}\text { Median survival: } 20 \text { weeks; } \\
\text { CR/PR: } 0 \% \text { (according to WHO criteria); } \\
\text { Survival analyses correlated with the tumor } \\
\text { stage before the therapy ( } 27.5 \text { weeks in } \\
\text { stage 3; } 14 \text { weeks in stage } 4 \text { ) }\end{array}$ & $\begin{array}{l}\text { No objective tumor } \\
\text { response; } \\
\text { maybe higher doses } \\
\text { needed for monotherapy }\end{array}$ \\
\hline Rosenberg et al ${ }^{80}$ & $\begin{array}{l}\text { Octreotide } 300 \mu \mathrm{g} / \text { day }+ \\
\text { tamoxifen } 20 \mathrm{mg} / \text { day }\end{array}$ & 12 & Median survival: 52 weeks & $\begin{array}{l}\text { Lack of patient number; } \\
\text { extent of disease was not } \\
\text { stated }\end{array}$ \\
\hline Fazeny et $\mathrm{al}^{43}$ & $\begin{array}{l}\text { Octreotide } 100-1500 \mu g / \text { day }+ \\
\text { goserelin acetate } 3.8 \mathrm{mg} / \mathrm{month}\end{array}$ & 14 & $\begin{array}{l}\text { ORR: } 7 \% \text {; } \\
\text { PR: one patient; } \\
\text { No change of disease: nine patients } \\
\text { (for up to } 27 \text { months); } \\
\text { PD: three patients (according to } \\
\text { WHO criteria) }\end{array}$ & $\begin{array}{l}\text { Lack of patient number; } \\
\text { no objective response } \\
\text { was observed }\end{array}$ \\
\hline Burch et $\mathrm{a}^{45}$ & $\begin{array}{l}\text { Octreotide } 600-1500 \mu g / \text { day } \\
\text { versus FU } 500 \mathrm{mg} / \mathrm{m}^{2} \text { IV bolus } \\
\text { for } 5 \text { consecutive days or } \\
\text { FU } 425 \mathrm{mg} / \mathrm{m}^{2}+\text { leucovorin } \\
20 \mathrm{mg} / \mathrm{m}^{2} / \text { day for } \\
5 \text { consecutive days }\end{array}$ & $\begin{array}{l}\text { 42: octreotide arm; } \\
\text { 22: FU arm } \\
\text { 22: FU + leucovorin } \\
\text { arm }\end{array}$ & $\begin{array}{l}\text { Median TTP: } 42 \text { days in octreotide arm, } \\
\text { I05 days in chemotherapy arm }(P=0.0 \mathrm{I})\end{array}$ & $\begin{array}{l}\text { No survival advantage } \\
\text { due to crossover to FU- } \\
\text { based chemotherapy at } \\
\text { the time of progression } \\
\text { on octreotide }\end{array}$ \\
\hline Sulkowski et al ${ }^{46}$ & Octreotide $6000 \mu \mathrm{g} /$ day & 49 & $\begin{array}{l}\text { CR/PR: } 0 \% \text {; } \\
\text { SD: } 19 \% \text { (according to RECIST criteria); } \\
\text { Median OS: } 21.4 \text { weeks; } \\
\text { Median PFS: } 9 \text { weeks }\end{array}$ & $\begin{array}{l}\text { No objective tumor } \\
\text { response; a Phase II } \\
\text { study; median survival } \\
\text { correlates with stage }\end{array}$ \\
\hline Cascinu et $\mathrm{a}^{47}$ & $\begin{array}{l}\text { Octreotide } 600 \mu \mathrm{g} / \text { day } \\
\text { versus BSC }\end{array}$ & $\begin{array}{l}\text { 55: octreotide arm; } \\
\text { 52: BSC arm } \\
\text { (total I07) }\end{array}$ & $\begin{array}{l}\text { Median survival: } 20 \text { versus II weeks } \\
(P<0.05)\end{array}$ & $\begin{array}{l}\text { No objective tumor } \\
\text { response }\end{array}$ \\
\hline
\end{tabular}

Abbreviations: BSC, best supportive care; CR, complete response; FU, fluorouracil; IV, intravenous; ORR, objective response rate; OS, overall survival; PD, progressive disease; PFS, progression-free survival; PR, partial response; RECIST, Response Evaluation Criteria in Solid Tumors; SD, stable disease; TTP, time to progression; WHO, World Health Organization.

There are limited data about the somatostatin analogs in pediatric tumors. Most of these data are not about the malignant diseases and almost all of the data have been obtained with octreotide. In general, benign conditions in which somatostatin analogs have been used are: massive gastrointestinal bleeding, complications of pancreatitis, chylothorax after cardiac surgery, chronic diarrhea, gastrointestinal fistulas, and dumping syndrome. ${ }^{55,56}$ Somatostatin analogs were used in endocrine tumors of the gastrointestinal tract, and biochemical and symptomatic responses were observed. ${ }^{56}$ Also, a case treated for thymic carcinoma with octreotide has been reported. In this case, biochemical response was observed and the clinical partial response was maintained for 8 months. ${ }^{57}$ In 21 patients with advanced osteosarcoma, only a biochemical response was observed with somatostatin analogs; a clinical response could not be obtained. ${ }^{58}$ In conclusion, there is a huge gap in the knowledge of somatostatin analogs in pediatric tumors and larger prospective studies should be done to clearly show any role of somatostatin analogs in pediatric tumors.

\section{Somatostatin analogs in neuroendocrine tumors}

Gastroenteropancreatic tumors are derived from pancreatic islet cells and the stomach, duodenum, and small intestine. Islet cell tumors are named according to the hormone(s) they secrete, and the symptoms are dependent on these hormone(s). Most of these tumors are metastatic and express SSTR to some degree. The presence of SSTR in neuroendocrine tumors is variable. The ratio of SSTR in SCLC is $40 \%$, while it is $80 \%-90 \%$ in carcinoid tumors. ${ }^{28,59-61}$ Carcinoid tumors are malignant tumors of enterochromaffin cells and originate from intestinal submucosa, bronchi, and pancreas. ${ }^{62}$ Most carcinoid tumors become symptomatic due to the carcinoid syndrome (flushing, diarrhea, tricuspid and pulmonary valve disease, bronchoconstriction, and pellagra) according to the 
increasing level of tumor products in systemic circulation. ${ }^{28}$ Somatostatin analogs improve symptomatic palliation. The tumoral regression rate is very low and additional treatment modalities are often used with somatostatin analogs. ${ }^{63}$ The stable disease ratio is approximately $50 \% .^{59,64,65} \mathrm{In}$ general, the symptomatic response and biochemical response rate with octreotide LAR versus long-acting lanreotide are $74.2 \%$ and $51.4 \%$ versus $67.5 \%$ and $39 \%$, respectively. ${ }^{65,66}$

In a Phase I study, 14 patients with carcinoid syndrome due to foregut, midgut, and hindgut carcinoids had their octreotide dose increased from $1500 \mu \mathrm{g}$ /day to $6000 \mu \mathrm{g} /$ day. The only dose-limiting side effect seen with the increasing dose was an injection site reaction. Urinary 5-hydroxyindoleacetic acid level remained stable in many of the patients. Radiological partial response was observed in four patients. Stable disease was seen in two patients and progressive disease was observed in seven patients. ${ }^{28}$ The Phase I study of lanreotide included 13 patients with foregut, midgut, and hindgut carcinoids, atypical carcinoid tumors, and SCLC. The initial dose was $2250 \mu \mathrm{g} / \mathrm{day}$, which was increased up to $9000 \mu \mathrm{g} /$ day. There were five patients with carcinoid syndrome. Partial response was observed in four patients. Stable disease and progressive disease were seen in one and eight patients, respectively. These studies showed that two somatostatin analogs could be used chronically with high doses. ${ }^{28}$

In a study including 39 patients, lanreotide $30 \mathrm{mg}$ was used for 6 months. Sixteen had previously received octreotide treatment. Although some symptomatic palliation was achieved, no radiological tumor response was observed. ${ }^{67}$ In another study including 16 patients with gastroenteropancreatic neuroendocrine tumors (ten carcinoid tumors, three nonfunctional pancreatic tumors, two Zollinger-Ellison syndrome, and one glucagonoma), eleven patients had previously received octreotide treatment. Octreotide LAR was used for a median 10.7 months. A statistically significant decrease was observed in most of the patients during the treatment. Fourteen patients had stable disease and two patients had progressive disease. ${ }^{68}$

In a study investigating the efficacy of octreotide LAR in patients with metastatic neuroendocrine tumors who progressed during lanreotide treatment, octreotide scintigraphy was positive prior to treatment in 13 of 15 patients. Octreotide LAR therapy resulted in $7 \%$ of patients with partial response, $40 \%$ with stable disease, and $53 \%$ with progressive disease. Stable disease was continued for a median 7.5 months. The median duration of treatment was 7 months. The overall biochemical response rate was $41 \%$ (33\% with complete response and $8 \%$ with partial response) and overall clinical response was $75 \% .{ }^{45}$ In the PROMID (Placebo Controlled, Double-Blind, Prospective, Randomized Study on the Effect of Octreotide LAR in the Control of Tumor Growth in Patients With Metastatic Neuroendocrine Midgut Tumors) trial, 85 previously untreated cases of metastatic well-differentiated neuroendocrine midgut tumors compared octreotide LAR with placebo. The median time to progression was 14.3 months and 6 months in the treatment and control arm, respectively $(P<005)$. The ratio of stable disease in the sixth month of the study was $67 \%$ in the treatment arm and $37.2 \%$ in the placebo arm. ${ }^{65,66,69,70}$

In a study with octreotide pamoate, which included twelve patients with malignant midgut carcinoid tumors, all of the patients had received previous systemic therapies and/or local treatment modalities for the metastatic lesions. Radiologically stable disease was observed in nine of twelve patients and progressive disease was observed in three. Median survival was 37 months when progressive disease was excluded. In progressive disease, the median survival was 12 months. Stabilization of tumor growth was observed in $75 \%$ of patients during the median survival of 12 months. Biochemical markers were stable in $58 \%$ of patients and decreased in $25 \% .{ }^{65,71}$

Prognostic factors for patients with metastatic midgut carcinoid tumor were examined in a study. The median survival was 8.06 years in patients receiving a somatostatin analog and 5.6 years for those who were not $(P<0.05)$. Some of these patients also received radionuclide-labeled somatostatin analogs. The median survival was 9.04 years in patients receiving radionuclide therapy and 7.21 years for those who were not $(P<0.05){ }^{72}$

Another somatostatin analog, pasireotide (SOM 230), affects more than one receptor. Pasireotide connects to SSTR1-3 and SSTR5 with high affinity. ${ }^{65}$ Therefore, SOM 230 could be used in cases resistant to other somatostatin analogs as well as responsive to them. Pasireotide was used in a study including 44 patients with metastatic gastroenteropancreatic neuroendocrine tumors. Symptom palliation was not observed with octreotide. Improvement in symptoms was observed in $27 \%$ of patients with pasireotide. . $5,70^{2}$

There are also studies with combination treatments including somatostatin analogs. In some of these, octreotide monotherapy was compared with a combination of octreotide and interferon- $\alpha$. Although there was no difference in terms of symptom palliation, combination therapy provided greater tumor reduction against octreotide monotherapy without any survival difference between the arms ${ }^{65}$ Progression-free 
survival $(96 \%$ versus $69 \%)$ and partial tumor response $(18 \%$ versus $0 \%$ ) were better with octreotide plus bevacizumab compared with octreotide plus pegylated interferon. ${ }^{73}$ The combination of everolimus and octreotide LAR was also investigated in 60 patients with advanced stage low-tomoderate neuroendocrine tumors and resulted in $22 \%$ of patients with partial response, $70 \%$ with stable disease, and $8 \%$ with progressive disease. Partial remission rate was better in endocrine tumors of the pancreas. Median progression-free survival was 60 weeks. The 1-, 2-, and 3-year survival rate was $83 \%, 81 \%$, and $78 \%$, respectively. ${ }^{74}$

When somatostatin analogs bind to the SSTRs, the internalization of the receptor-peptide complex stimulates the retention of the radiopeptide in tumors expressing the receptor. In order to stabilize the molecule, the peptide labeled with a radioisotope is bound to a chelator. Due to the small size of the complex, clearance from the blood occurs rapidly, which makes this strategy tolerable in terms of systemic toxicity. ${ }^{75}$ With this principle peptide, radioreceptor treatment has been developed. Treatment of neuroendocrine tumors with radionuclide-labeled somatostatin analogs has been reported to yield favorable results. Partial remission was observed in $10 \%-25 \%$ of patients with yttrium-90-dodecanetetraacetic acid-tyrosine ${ }^{3}$-octreotide (90Y-DOTATATE). ${ }^{65}$ In Krenning et al's study, indium-111-diethylenetriaminepentaacetic acid-octreotide was applied. Of the 30 patients, there were seven patients with progressive disease, eight with stable disease, and six with partial remission. ${ }^{75}$ In a study of 90Y-DOTATATE, 46 patients with neuroendocrine tumor were included and $89.1 \%$ of them were metastatic. Thirteen, three, and ten of these patients received prior chemotherapy, radiotherapy, and long-acting somatostatin analog treatment, respectively. 90Y-DOTATATE was given to 45 patients. After 12 months of follow-up, $47 \%$ had stable disease, $31 \%$ had partial remission, and $9 \%$ had progressive disease. Progression-free survival was 37.4 months. ${ }^{76}$ In a study of indium-111-pentetreotid, partial remission and obvious tumor necrosis was observed in $8 \%$ and $27 \%$ of patients, respectively. Symptomatic and hormonal response rates were $62 \%$ and $18 \%$, respectively. Median survival was 18 months and this was longer than expected. ${ }^{77}$ In most of the studies with 90Y-DOTATATE, similar responses were observed and objective tumor response ranged between $10 \%-30 \%$. 90Y-DOTA-lanreotide, unlike indium-111-octreotide, connected to SSTR4 with high affinity. In the MAURITIUS (Multicenter Analysis of a Universal Receptor Imaging and Treatment Initiative, a European Study) study, 20.5\% of patients achieved partial response and $43.6 \%$ achieved stable disease after the 3-year follow-up with 90Y-DOTAlanreotide. 177-lutetium-DOTATATE therapy was used in 34 patients with gastroenteropancreatic tumors, in which complete remission was observed in 3\%, partial remission in $35 \%$, stable disease in $41 \%$, and progressive disease in $21 \%$ of patients. Studies have shown that weak positivity of diagnostic indium-111-octreotide scintigraphy, poor general condition, hepatic involvement, and advanced stage disease leads to a lower remission rate..$^{63,75}$

The overall response rate was $24 \%$ in 41 patients (neuroendocrine gastroenteropancreatic and bronchial tumors) treated with 90Y-DOTATATE-labeled somatostatin analog. This rate was $36 \%$ for endocrine pancreatic tumors. The complete response rate and partial response rate was $2 \%$ and $22 \%$, respectively. Stable disease and progressive disease was observed in $49 \%$ and $15 \%$ of patients, respectively. ${ }^{60}$ Imhof et al applied the same agent to 1109 patients with 25 different types of neuroendocrine tumors. The morphological tumor response rate was $34.1 \%$. Stable disease and complete remission was observed in $5.2 \%$ and $0.6 \%$ of patients, respectively. The median survival was 94.6 months from diagnosis. ${ }^{78}$

In conclusion, somatostatin analogs remain the main symptomatic therapeutic modality for neuroendocrine tumors. In general, their effects are limited to symptom control and stabilization of the disease. Decrease in tumor size rarely occurs with current somatostatin analogs. There are minor differences between octreotide LAR and lanreotide in controlling neuroendocrine tumor hormone release. Inclusion criteria, cotreatments, and endpoints varied between studies. Therefore, it is not possible to do a direct comparison of the analogs in these studies. However, the PROMID study demonstrated a clear effect of octreotide on the time to tumor progression and disease stabilization compared with placebo. For lanreotide, the results of a study that is examining the efficacy and safety of lanreotide autogel in tumor stabilization of patients with progressive neuroendocrine tumors is expected.

\section{Conclusion}

Most of the studies evaluating the effect of somatostatin analogs in breast cancer have included a small number of patients with advanced stage or metastatic disease, and have shown that somatostatin analogs alone or in combination with other agents have limited antitumoral effect. Somatostatin analogs have not been shown to induce an obvious decrease in tumor burden in SCLC, but could control the symptoms of ectopic hormone secretion (adrenocorticotropic hormone, growth hormone-releasing hormone). Lanreotide has no effect in 
advanced stage SCLC. It is clear that somatostatin analogs have only limited antitumoral effect when used as a monotherapy in prostate cancer. However, favorable results have been reported when administered in combination with prostate cancer-specific anticancer agents. In metastatic prostate cancer, somatostatin analogs induce a statistically significant decrease in bone pain and an increase in Karnofsky performance status. Studies in gastrointestinal cancer did not show an objective tumor response and survival advantage with somatostatin analogs. Endocrine tumors of the liver could be an exception. Symptomatic and biochemical responses have been reported in gastrointestinal cancer, maybe due to inhibition of gastrointestinal secretion by somatostatin analogs. There is limited data about somatostatin analogs in pediatric tumors. In general, octreotide has been used for benign conditions in pediatric cancer patients. There are minor differences between octreotide LAR and lanreotide in controlling neuroendocrine tumor hormone release. In neuroendocrine tumors of the gastrointestinal system and pancreas, favorable symptomatic and biochemical responses have been achieved with somatostatin analogs. Additionally, antiproliferative activity has been clearly shown with octreotide in metastatic midgut neuroendocrine tumors.

\section{Disclosure}

The authors report no conflicts of interest in this work.

\section{References}

1. Weckbecker G, Raulf F, Stolz B, Bruns C. Somatostatin analogs for diagnosis and treatment of cancer. Pharmacol Ther. 1993;60(2): 245-264.

2. Zarogoulidis K, Eleftheriadou E, Kontakiotis T, et al. Long acting somatostatin analogues in combination to antineoplastic agents in the treatment of small cell lung cancer patients. Lung Cancer. 2012;76(1):84-88.

3. PatelYC. Somatostatin and its receptor family. Front Neuroendocrinol. 1999;20(3):157-198.

4. O'Byrne KJ, Schally AV, Thomas A, Carney DN, Steward WP. Somatostatin, its receptors and analogs, in lung cancer. Chemotherapy. 2001;47(Suppl 2):78-108.

5. Garcia de la Torre N, Wass JA, Turner HE. Antiangiogenic effects of somatostatin analogues. Clin Endocrinol (Oxf). 2002;57(4):425-441.

6. Dasgupta P. Somatostatin analogues: multiple roles in cellular proliferation, neoplasia, and angiogenesis. Pharmacol Ther. 2004;102(1): $61-85$.

7. Vainas IG. Octreotide in the management of hormone-refractory prostate cancer. Chemotherapy. 2001;47(Suppl 2):109-126.

8. Scarpignato C, Pelosini I. Somatostatin analogs for cancer treatment and diagnosis: an overview. Chemotherapy. 2001;47(Suppl 2):1-29.

9. Lancranjan I, Bruns C, Grass P, et al. Sandostatin LAR ${ }^{\circledR}$ : pharmacokinetics, pharmacodynamics, efficacy, and tolerability in acromegalic patients. Metabolism. 1995;44(Suppl 1):18-26.

10. Pollak M. The potential role of somatostatin analogues in breast cancer treatment. Yale J Biol Med. 1997;70(5-6):535-539.

11. Woltering EA, Watson JC, Alperin-Lea RC, et al. Somatostatin analogs: angiogenesis inhibitors with novel mechanisms of action. Invest New Drugs. 1997;15(1):77-86.
12. Rubin J, Ajani J, Schirmer W, et al. Octreotide acetate long-acting formulation versus open-label subcutaneous octreotide acetate in malignant carcinoid syndrome. J Clin Oncol. 1999;17(2):600-606.

13. Ludlam WH, Anthony L. Safety review: dose optimization of somatostatin analogs in patients with acromegaly and neuroendocrine tumors. Adv Ther. 2011;28(10):825-841.

14. Cozzi R, Dallabonzana D, Attanasio R, Barausse M, Oppizzi G. A comparison between octreotide-LAR and lanreotide-SR in the chronic treatment of acromegaly. Eur J Endocrinol. 1999;141(3):267-271.

15. Chanson P, Boerlin V, Ajzenberg C, et al. Comparison of octreotide acetate LAR and lanreotide SR in patients with acromegaly. Clin Endocrinol (Oxf). 2000;53(5):577-586.

16. Murray RD, Melmed S. A critical analysis of clinically available somatostatin analog formulations for therapy of acromegaly. $J$ Clin Endocrinol Metab. 2008;93(8):2957-2968.

17. Boccardo F, Amoroso D. Management of breast cancer: is there a role for somatostatin and its analogs? Chemotherapy. 2001;47(Suppl 2): 62-77.

18. Vennin P, Peyrat JP, Bonneterre J, Louchez MM, Harris AG, Demaille A. Effect of the long-acting somatostatin analogue SMS 201-995 (Sandostatin) in advanced breast cancer. Anticancer Res. 1989;9(1):153-155.

19. O’Byrne KJ, Dobbs N, Propper DJ, et al. Phase II study of RC-160 (vapreotide), an octapeptide analogue of somatostatin, in the treatment of metastatic breast cancer. Br J Cancer. 1999;79(9-10): 1413-1418.

20. Stolfi R, Parisi AM, Natoli C, Iacobelli S. Advanced breast cancer: response to somatostatin. Anticancer Res. 1990;10(1):203-204.

21. Anderson E, Ferguson JE, Morten H, Shalet SM, Robinson EL, Howell A. Serum immunoreactive and bioactive lactogenic hormones in advanced breast cancer patients treated with bromocriptine and octreotide. Eur J Cancer. 1993;29A(2):209-217.

22. Canobbio L, Cannata D, Miglietta L, Boccardo F. Somatuline (BIM 23014) and tamoxifen treatment of postmenopausal breast cancer patients: clinical activity and effect on insulin-like growth factor-I (IGF-I) levels. Anticancer Res. 1995;15(6B):2687-2690.

23. Di Leo A, Ferrari L, Bajetta E, et al. Biological and clinical evaluation of lanreotide (BIM 23014), a somatostatin analogue, in the treatment of advanced breast cancer. A pilot study by the ITMO group. Italian Trials in Medical Oncology. Breast Cancer Res Treat. 1995;34(3):237-244.

24. Ingle JN, Suman VJ, Kardinal CG, et al. A randomized trial of tamoxifen alone or combined with octreotide in the treatment of women with metastatic breast carcinoma. Cancer. 1999;85(6):1284-1292.

25. Bajetta E, Procopio G, Ferrari L, et al. A randomized, multicenter prospective trial assessing long-acting release octreotide pamoate plus tamoxifen as a first line therapy for advanced breast carcinoma. Cancer. 2002;94(2):299-304.

26. Bontenbal M, Foekens JA, Lamberts SW, et al. Feasibility, endocrine and anti-tumour effects of a triple endocrine therapy with tamoxifen, a somatostatin analogue and an prolactin lowering drug in postmenopausal metastatic breast cancer: a randomized study with long-term follow-up. Br J Cancer. 1998;77(1):115-122.

27. Macaulay VM, Smith IE, Everard MJ, Teale JD, Reubi JC, Millar JL. Experimental and clinical studies with somatostatin analogue octreotide in small cell lung cancer. Br J Cancer. 1991;64(3):451-456.

28. Anthony L, Johnson D, Hande K, et al. Somatostatin analogue Phase I trials in neuroendocrine neoplasms. Acta Oncol. 1993;32(2): 217-223.

29. van Hoek M, Hofland LJ, de Rijke YB, et al. Effects of somatostatin analogs on a growth hormone-releasing hormone secreting bronchial carcinoid, in vivo and in vitro studies. $J$ Clin Endocrinol Metab. 2009;94(2):428-433.

30. Fainstein Day P, Frohman L, Garcia Rivello H, et al. Ectopic growth hormone-releasing hormone secretion by a metastatic bronchial carcinoid tumor: a case with a non hypophysial intracranial tumor that shrank during long acting octreotide treatment. Pituitary. 2007;10(3): 311-319. 
31. Zatelli MC, Maffei P, Piccin D, et al. Somatostatin analogs in vitro effects in a growth hormone-releasing hormone-secreting bronchial carcinoid. J Clin Endocrinol Metab. 2005;90(4):2104-2109.

32. Bearz A, Lleshi A, Perin T, et al. Small cell lung cancer in an elderly patient: efficacy of somatostatin analog treatment, a case report. Onkologie. 2011;34(3):117-120.

33. Parmar H, Charlton CD, Phillips RH, et al. Therapeutic response to somatostatin analogue, BIM 23014, in metastatic prostatic cancer. Clin Exp Metastasis. 1992;10(1):3-11.

34. Logothetis CJ, Hossan EA, Smith TL. SMS 201-995 in the treatment of refractory prostatic carcinoma. Anticancer Res. 1994;14(6B): 2731-2734.

35. Vainas I, Pasaitou K, Galaktidou G, et al. The role of somatostatin analogues in complete antiandrogen treatment in patients with prostatic carcinoma. J Exp Clin Cancer Res. 1997;16(1):119-126.

36. Koutsilieris M, Mitsiades C, Dimopoulos T, Ioannidis A, Ntounis A, Lambou T. A combination therapy of dexamethasone and somatostatin analog reintroduces objective clinical responses to LHRH analog in androgen ablation-refractory prostate cancer patients. J Clin Endocrinol Metab. 2001;86(12):5729-5736.

37. Dimopoulos MA, Kiamouris C, Gika D, et al. Combination of LHRH analog with somatostatin analog and dexmethasone versus chemotherapy in hormone-refractory prostate cancer: a randomized Phase II study. Urology. 2004;63(1):120-125.

38. Mitsiades CS, Bogdanos J, Karamanolakis D, Milathianakis C, Dimopoulos T, Koutsilieris M. Randomized controlled clinical trial of a combination of somatostatin analog and dexamethasone plus zolendronate vs zolendronate in patients with androgen ablation-refractory prostate cancer. Anticancer Res. 2006;26(5B): 3693-3700.

39. Mitsogiannis IC, Skolarikos A, Deliveliotis C. Somatostatin analog lanreotide in the treatment of castration-resistant prostate cancer (CRPC). Expert Opin Pharmacother. 2009;10(3):493-501.

40. Gonzalez-Barcena D, Schally AV, Vadillo-Buenfil M, et al. Response of patients with advanced prostatic cancer to administration of somatostatin analogue RC-160 (vapreotide) at the time of relapse. Prostate. 2003;56(3):183-191.

41. Cascinu S, Catalano V, Giordani P, Baldelli AM, Agostinelli R, Catalano G. Gastrointestinal cancer refractory to chemotherapy: a role for octreotide? Chemotherapy. 2004;47(Suppl 2):127-133.

42. Klijn JG, Hoff AM, Planting AS, et al. Treatment of patients with metastatic pancreatic and gastrointestinal tumours with the somatostatin analogue Sandostatin: a Phase II study including endocrine effects. Br J Cancer. 1990;62(4):627-630.

43. Fazeny B, Baur M, Prohaska M, et al. Octreotide combined with goserelin in the therapy of advanced pancreatic cancer - results of a pilot study and review of the literature. J Cancer Res Clin Oncol. 1997;123(1):45-52.

44. Friess H, Buchler M, Beglinger C, et al. Low-dose octreotide treatment is not effective in patients with advanced pancreatic cancer. Pancreas. 1993;8(5):540-545.

45. Burch PA, Block M, Schroeder G, et al. Phase III evaluation of octreotide versus chemotherapy with 5-fluorouracil or 5-fluorouracil plus leucovorin in advanced exocrine pancreatic cancer: a North Central Cancer Treatment Group study. Clin Cancer Res. 2000;6(9): 3486-3492.

46. Sulkowski U, Buchler M, Pederzoli P, et al. A Phase II study of highdose octreotide in patients with unresectable pancreatic carcinoma. Eur J Cancer. 1999;35(13):1805-1808.

47. Cascinu S, Del Ferro E, Catalano G. A randomised trial of octreotide vs best supportive care only in advanced gastrointestinal cancer patients refractory to chemotherapy. Br J Cancer. 1995;71(1):97-101.

48. Iftikhar SY, Watson SA, Morris DL. The effect of long acting somatostatin analogue SMS 201.995 therapy on tumour kinetic measurements and serum tumour marker concentrations in primary rectal cancer. Br J Cancer. 1991;63(6):971-974.
49. Kouroumalis EA. Octreotide for cancer of the liver and biliary tree. Chemotherapy. 2001;47(Suppl 2):150-161.

50. Becker G, Allgaier HP, Olschewski M, Zahringer A, Blum HE; HECTOR Study Group. Long-acting octreotide versus placebo for treatment of advanced HCC: a randomized controlled double-blind study. Hepatology. 2007;45(1):9-15

51. Ji XQ, Ruan XJ, Chen H, Chen G, Li SY, Yu B. Somatostatin analogues in advanced hepatocellular carcinoma: an updated systematic review and meta-analysis of randomized controlled trials. Med Sci Monit. 2011;17(8):RA169-RA176.

52. Zhao B, Zhao H, Zhao N, Zhu XG. Cholangiocarcinoma cells express somatostatin receptor subtype 2 and respond to octreotide treatment. J Hepatobiliary Pancreat Surg. 2002;9(4):497-502.

53. Gaal J, de Krijger RR. Neuroendocrine tumors and tumor syndromes in childhood. Pediatr Dev Pathol. 2010;13(6):427-441.

54. Dishop MK, Kuruvilla S. Primary and metastatic lung tumors in the pediatric population: a review and 25-year experience at a large children's hospital. Arch Pathol Lab Med. 2008;132(7):1079-1103.

55. Al-Hussaini A, Butzner D. Therapeutic applications of octreotide in pediatric patients. Saudi J Gastroenterol. 2012;18(2):87-94.

56. Heikenen JB, Pohl JF, Werlin SL, Bucuvalas JC. Octreotide in pediatric patients. J Pediatr Gastroenterol Nutr. 2002;35(5):600-609.

57. Kertesz GP, Hauser P, Varga P, Dabasi G, Schuler D, Garami M. Advanced pediatric inoperable thymus carcinoma (type $\mathrm{C}$ thymoma): case report on a novel therapeutic approach. J Pediatr Hematol Oncol. 2007;29(11):774-775.

58. Mansky PJ, Liewehr DJ, Steinberg SM, et al. Treatment of metastatic osteosarcoma with the somatostatin analog OncoLar: significant reduction of insulin-like growth factor-1 serum levels. J Pediatr Hematol Oncol. 2002;24(6):440-446.

59. Leong WL, Pasieka JL. Regression of metastatic carcinoid tumors with octreotide therapy: two case reports and review of the literature. J Surg Oncol. 2002;79(3):180-187.

60. Waldherr C, Pless M, Maecke HR, Haldemann A, Mueller-Brand J. The clinical value of [90Y-DOTA]-D-Phe1-Tyr3-octreotide (90Y-DOTATOC) in the treatment of neuroendocrine tumours: a clinical Phase II study. Ann Oncol. 2001;12(7):941-945.

61. Ricci S, Antonuzzo A, Galli L, et al. Octreotide acetate long-acting release in patients with metastatic neuroendocrine tumors pretreated with lanreotide. Ann Oncol. 2000;11(9):1127-1130.

62. Yalcin S, Oyan B, Bayraktar Y. Current medical treatment of pancreatic neuroendocrine tumors. Hepatogastroenterology. 2007;54(73): 278-284.

63. Kwekkeboom DJ, Bakker WH, Kam BL, et al. Treatment of patients with gastro-entero-pancreatic (GEP) tumours with the novel radiolabelled somatostatin analogue [177Lu-DOTA(0),Tyr3]octreotate. Eur J Nucl Med Mol Imaging. 2003;30(3):417-422.

64. de Herder WW, van der Lely AJ, Lamberts SW. Somatostatin analogue treatment of neuroendocrine tumors. Postgrad Med J. 1996;72(849):403-408.

65. Yalcin S. Advances in the systemic treatment of pancreatic neuroendocrine tumors. Cancer Treat Rev. 2011;37(2):127-132.

66. Modlin IM, Pavel M, Kidd M, Gustafsson BI. Review article: somatostatin analogues in the treatment of gastroenteropancreatic neuroendocrine (carcinoid) tumours. Aliment Pharmacol Ther. 2010;31(2):169-188

67. Ruszniewski P, Ducreux M, Chayvialle JA, et al. Treatment of the carcinoid syndrome with the long-acting somatostatin analogue lanreotide: a prospective study in 39 patients. Gut. 1996;39(2): 279-283.

68. Tomasetti P, Migliori M, Corinaldesi R, Gullo L. Treatment of gastroenteropancreatic neuroendocrine tumors with octreotide LAR. Aliment Pharmacol Ther. 2000;14(5):557-560.

69. Strosberg J, Kvols L. Antiproliferative effect of somatostatin analogs in gastroenteropancreatic neuroendocrine tumors. World Gastroenterol. 2010;16(24):2963-2970. 
70. Walter T, Brixi-Benmansour H, Lombard-Bohas C, Cadiot G. New treatment strategies in advanced neuroendocrine tumours. Dig Liver Dis. 2012;44(2):95-105.

71. Welin SV, Janson ET, Sundin A, et al. High-dose treatment with a long-acting somatostatin analogue in patients with advanced midgut carcinoid tumours. Eur J Endocrinol. 2004;151(1):107-112.

72. Ahmed A, Turner G, King B, et al. Midgut neuroendocrine tumours with liver metastases: results of the UKINETS study. Endocr Relat Cancer. 2009;16(3):885-894.

73. Yao JC, Phan A, Hoff PM, et al. Targeting vascular endothelial growth factor in advanced carcinoid tumor: a random assignment Phase II study of depot octreotide with bevacizumab and pegylated interferon alpha-2b. J Clin Oncol. 2008;26(8):1316-1323.

74. Duran I, Kortmansky J, Singh D, et al. A Phase II clinical and pharmacodynamic study of temsirolimus in advanced neuroendocrine carcinomas. Br J Cancer. 2006;95(9):1148-1154.

75. Kaltsas GA, Papadogias D, Makras P, Grossman AB. Treatment of advanced neuroendocrine tumours with radiolabelled somatostatin analogues. Endocr Relat Cancer. 2005;12(4):683-699.
76. Sowa-Staszczak A, Pach D, Kunikowska J, et al. Efficacy and safety of 90Y-DOTATATE therapy in neuroendocrine tumours. Endokrynol Pol. 2011;62(5):392-400.

77. Anthony LB, Woltering EA, Espenan GD, Cronin MD, Maloney TJ, McCarthy KE. Indium-111-pentetreotide prolongs survival in gastroenteropancreatic malignancies. Semin Nucl Med. 2002;32(2): $123-132$.

78. Imhof A, Brunner P, Marincek N, et al. Response, survival, and longterm toxicity after therapy with the radiolabeled somatostatin analogue [90Y-DOTA]-TOC in metastasized neuroendocrine cancers. J Clin Oncol. 2011;29(17):2416-2423.

79. Manni A, Boucher AE, Demers LM, Harvey HA, Lipton A, Simmonds MA, Bartholomew M. Endocrine effects of combined somatostatin analog and bromocriptine therapy in women with advanced breast cancer. Breast Cancer Res Treat. 1989;14:289-298.

80. Rosenberg L, Barkun AN, Denis MH, Pollak M. Low-dose octreotide and tamoxifen in the treatment of adenocarcinoma of the pancreas. Cancer. 1995; 75:23-28.

\section{Publish your work in this journal}

OncoTargets and Therapy is an international, peer-reviewed, open access journal focusing on the pathological basis of all cancers, potential targets for therapy and treatment protocols employed to improve the management of cancer patients. The journal also focuses on the impact of management programs and new therapeutic agents and protocols on

\section{Dovepress}

patient perspectives such as quality of life, adherence and satisfaction The manuscript management system is completely online and includes a very quick and fair peer-review system, which is all easy to use. Visit http://www.dovepress.com/testimonials.php to read real quotes from published authors. 